\title{
EVALUATION OF THE IMPACTS OF NON-OIL EXPORTS ON ECONOMIC GROWTH IN NIGERIA BETWEEN 1986-2018
}

\section{Chinyere Faith Ekwunife ${ }^{1}$, Samuel Ngozichikanma Nwosu², Nkama Orji Nkama ${ }^{3}$ and Chinwoke Remiguis Ejinkonye ${ }^{4}$}

${ }^{1}$ Department of Banking and Finance, Evangel University, Akaeze, Ebonyi State Email: cf.ekwunife@gmail.com

${ }^{2}$ Department of Accounting, Evangel University, Akaeze, Ebonyi State

Email: samca880@gmail.com

${ }^{3}$ Department of Accounting, Evangel University, Akaeze, Ebonyi State Email: nkamankama4real@gmail.com

${ }^{4}$ Department of Banking and Finance, Evangel University, Akaeze, Ebonyi State Email: rejinkonye@gmail.com

Cite this article:

Chinyere F.E., Samuel N.N., Nkama O.N., Chinwoke R.E. (2021), Evaluation of the Impacts of Non-Oil Exports on Economic Growth in Nigeria Between 1986-2018. African Journal of Accounting and Financial Research 4(3), 39-64. DOI: 10.52589/AJAFRMUN5QZ7W.

\section{Manuscript History}

Received: 1 July 2021

Accepted: 3 Aug 2021

Published: 17 Aug 2021

Copyright $\odot 2020$ The Author(s). This is an Open Access article distributed under the terms of Creative Commons AttributionNonCommercial-NoDerivatives 4.0 International (CC BY-NC-ND 4.0 ), which permits anyone to share, use, reproduce and redistribute in any medium, provided the original author and source are credited.
ABSTRACT: Non-oil exports have been seen to be very vital in economic growth and development, especially for developing economics. Despite the poor contribution of non-oil exports to economic growth in Nigeria, this study is inspired by the inconsistencies in empirical findings regarding the connection and effect of non-oil exports on the economy. The objective of the study was to determine the effect of non-oil exports on economic growth in Nigeria. An ex-post facto research design was adopted. The time frame of thirty three (33) years, from 1986 to 2018 was adopted to allow for a large number of observations which will improve the robustness of the results. The data was obtained from the Central Bank of Nigeria (CBN) statistical bulletin of 2017. The Ordinary Least Square (OLS) estimation technique was applied in guesstimating the models. E-views 9.0 was the econometric software used for the analysis. The result revealed that non-oil exports have no significant effect on the growth rate of real gross domestic product, agricultural contribution to real gross domestic product is not significantly affected by exports of non-oil products even though there is evidence of a positive but insignificant correlation between them. Manufacturing capacity utilization is not significantly influenced by variation in Nigeria's non-oil exports. Nonoil exports are positively associated with manufacturing capacity utilization. Economic growth in Nigeria has not been significantly affected by non-oil exports despite the various non-oil promotion strategies by the government. We recommend that cost and access to financial services for non-oil exporters be moderate or relaxed.

KEYWORDS: Non-Oil Exports; Economic Growth; Real Gross Domestic Product; Nigeria. 


\section{INTRODUCTION}

\section{Background of to the Study}

Non-oil export has been seen to be very vital in economic growth and development, especially for developing economics. In Nigeria, non-oil exports have been found to perform as the engine of growth through high productivity exports (Ekiran, Awe and Ogunjobi, 2014, Raj and Chand 2017). The implementation of articulated policies by the Federal Government of Nigeria in a bid to diversify the economy owing to fall in oil prices in the international oil market points to the importance of non-oil exports in economic sustainability. The fall in oil prices in the international oil market in 2016 resulted in a serious foreign exchange rate crisis in Nigeria. This, coupled with macroeconomic instability put the economy of Nigeria in recession which is the first in recent time. Provisional data from the Central Bank of Nigeria economic report of the first quarter of 2017 put total non-oil export earnings at US $\$ 0.87$ billion, an increase by $85.5 \%$ above the level in the fourth quarter of 2016, but declined by $14.7 \%$ at the end of the corresponding period of 2016. Prior to the discovery of oil; in the 50s and 60s era, non-oil exports through agricultural products were the mainstay of the Nigerian economy. During the first period after independence and based on the standpoint of occupational distribution and contribution to the gross domestic product, non-oil exports through agriculture was the leading sector contributing about $70 \%$ of the Gross Domestic Product (GDP); employing about the same percentage of the working population, and accounting for about $90 \%$ of foreign earnings and Federal Government revenue (Gbaiye, Ogundipe, Osabuohiem, Olugbire, Adeniran, Bolaji-Olutunji, Awodele \& Aduradola, 2013). However, the reverse is the case at present as Nigeria foreign exchange earnings are virtually dependent on crude oil exports as against agricultural products. The World bank (2016) stated in clear terms that the Nigerian oil and gas sector accounts for only $11 \%$ of gross domestic products and employs less than $3 \%$ of Nigeria's working population and still accounts for more than $90 \%$ of foreign exchange earnings. The implication of this is that the dynamics of the economy is at the whims and caprices of the price of oil, which for the most part, has been volatile (Kromtit, Kanadi, Ndangra \& Lado, 2017)

Developing countries desire to achieve sustainable growth and development and exports are generally perceived as a motivating factor to achieving this, and meeting this challenge is crucial for the Economic Community of West African States (ECOWAS) to reduce food dependency and improve the current unfavorable terms of trade by processing products and increasing value added (Edeme, Ifelunini \& Nkalu, 2016). Subsequent to the assertion of Shah, Abrar-ul-haq and Farooq (2015), economic growth is a primary and a crucial aim of developing countries, and a recurrent theme in the trade and development literature is the role of exports as it is considered as an engine for economic growth.

Considering the location of Nigeria on the global spectrum and its associated climatology, it is not surprising to find the country endowed with an expansive fertile agricultural land, numerous rivers, streams and lakes, forest of varying types and grasslands (Ekiran, Awe and Ogunjobi, 2014). While acknowledging, Njiforti (2007) and Adubi (1996), Ekiran, Awe and Ogunjobi (2014) note further that these resources create an impression which indicates that if these enormous resources are well managed and maintained, there could emerge in the country, a vibrant agricultural sector supportive of food and raw materials self-sufficiency for the large population and industrial sector respectively. From the assertion of Kautoke-Holaani 
(2008), non-oil exports through agriculture has in the past taking Tonga out of economic recession and made Tonga one of the fastest economics in the South Pacific Island countries.

Studies have been documented on the alleged linkage between economic growth and non-oil exports. The arguments can be seen in classical economic gains from specialization (Shah, Abrar-ul-haq and Farooq 2015). In the midst of recession and exchange rate crisis experienced in the economy, there has been call from various stakeholders for the diversification of the economy, to avoid a situation where the economy would be engulfed in crisis consequent to changes in oil prices in the international market. That notwithstanding, it is pertinent to note that contrary to the general impression that the economy requires diversification, what is in fact required is the diversification of Nigeria's sources of income, and the strengthening of the nonoil sectors of the economy (Amasike, 2017). From the studies carried out in the Nigeria environment, researcher's proxied economic growth with real gross domestic product but this study incorporated agricultural sectoral contribution to real gross domestic product as well as industrial performance through manufacturing capacity utilization.

\section{Statement of the Problem}

Despite the poor contribution of non-oil exports to economic growth in Nigeria, this study is inspired by two misleading issues in literature on the alleged linkage between non-oil exports and economic growth. First, despite decades of research on non-oil exports and economic growth models, especially for developing countries like Nigeria that have abundant oil resources. Studies such as Sha, Abrar-ul-haq and Farroq (2015), Simasikuk and Sheefeni (2017) and Ogunjimi, Aderinto and Ogunro (2015) among others showed that non-oil exports has negative but insignificant effect on economic growth of Pakistan, Namibia and Nigeria respectively. On the contrary, Ekiran, Awe and Ogunjobi (2014) and Raj and Chand (2017) envisaged a positive and significant effect of non-oil exports on economic growth of Nigeria and Fiji accordingly.

Secondly, the direction of causal relationship between non-oil exports and economic growth is still not clear and not limited to developing economies. Ohlan (2016), Eze (2017), Mohsen (2015) and Alam and Myovella (2016) among others came forward to say that economic growth in India, Nigeria, Syria and Tanzania follow the direction of non-oil exports. Unfortunately, these claims were countered by Ouma, Kimani and Manyasa (2016) that empirically stated that neither does economic growth follow in Burundi, Tanzania and Uganda. In view of the inconsistencies in empirical findings regarding the connection and effect of nonoil exports on economy it becomes pertinent to revisit this nexus in the context of Nigeria owing to poor contribution of this sector (non-oil exports) to economic growth by using up-todate data on the variables of interest.

\section{Objectives of the Study}

1. Determine the effect of non-oil exports on Nigeria's real gross domestic product.

2. Ascertain the effect of non-oil exports on Nigeria's agricultural contribution to real gross domestic product.

3. Evaluate the effect of non-oil exports on Nigeria's manufacturing capacity utilization. 


\section{Hypotheses of the Study}

1. H0: Non-oil exports has no significant effect on Nigeria's real gross domestic product

2. H1: Non-oil exports have no significant effect on Nigeria's agricultural contribution to real gross domestic product.

3. H0: Non-oil exports have no significant effect on Nigerian manufacturing capacity utilization.

\section{Review Of Related Literature}

\section{The concept of Non-oil Export}

Non-oil exports are part of a country's total domestic exports. In Nigeria, exports are divided into two: oil and non-oil exports. Products from agriculture, mining, quarrying and industrial sectors of the Nigerian economy outside the crude Oil exports which are shipped to other countries of the world are grouped as non-oil exports. Non-oil exports are products, which are produced within the country in the agricultural, mining, quarrying and industrial sector that are sent outside the country to generate revenue for the growth of the economy, excluding oil products (Jeff-Anyene, Ezu \& Ananwude, 2016). According to the Central Bank of Nigeria (2015), non-oil exports include cashew nuts, cocoa beans, coffee, cotton, cow horns, ginger, and groundnuts. Arabic gum, rubber, etc. that are not crude oil. Agriculture is the primary non-oil product sector, which provides food, and fiber for the economy, while industry, as the modern sector, produces manufactured goods. The non-oil exports sector of the Nigerian economy, which is dominated by agriculture, played significant roles in the economy before the advent of crude oil. It contributed largely to Nigeria's Gross Domestic Product (GDP) and it was also the primary source of foreign exchange. The discovery of crude oil in Nigeria has had both negative and positive effects on the economy. Negatively, the effect of oil exploration on the oil well communities and its inhabitants has led to many issues in the country's political, social and economic life (Fiiwe \& Turakpe, 2017). Although it is not questionable if the country has had large proceeds from the export of petroleum products, the effect of such proceeds on the growth of the Nigerian economy is questionable.

\section{Economic Growth}

Economic growth is the rise in the total output of a country over a specified period of time (Anyanwu, Ananwude \& Okoye, 2017). According to Ijirshar (2015), economic growth is an increase in the capacity of an economy to produce goods and services, compared from one period of time to another. The growth of an economy over the time is widely measured with Gross Domestic Product (GDP). The GDP may be nominal GDP or real GDP, the nominal GDP does not take account the devastating effect of inflation, but the latter is adjusted to capture the likely impact of inflation. Real gross domestic product measures the value of goods and services produced over a given period of time. In other words, it is a measure of domestic production by an economy within a stated period of time and evaluated in monetary value. Real gross domestic product is widely calculated on purchasing power parity and taking into consideration the probable effect of inflation (Anyanwu, Adigwe \& Ananwude, 2017). Nigeria's economic performance since independence in 1960 has been decidedly mediocre, 
despite the availability and expenditure of a colossal amount of foreign exchange derived mainly from its oil and gas resources, economic growth has been weal and the incidences of poverty has increased (Ismaila, 2016).

\section{Agricultural Contribution to Real Gross Domestic Product}

This measures the proportion of the real gross domestic income that is accounted for by the agricultural sector. Agriculture is an important economic sector influencing the basis industrial growth and development of most economies in the world. This sector is also regarded as the engine of growth and development by most nations, likewise the oil sector in cases of countries with abundance of oil. Therefore, improvement of major sartorial aspects that contributes to nations' economy can help in poverty alleviation of most third world countries. Similarly, recent studies on the cause of growth and development have been identifying sartorial transformation of most nations as a way for their economic liberation. Nigeria as a country considered in this study has its major foreign income from non-oil exports during the last decade before pattern changed when oil suddenly became of crucial position in the world economy. The performance of agricultural export in the past three decades leaves little or nothing desirable in spite of the efforts to promote non-oil exports in Nigeria. For these reasons, if Nigerian economy is to be returned to the path of sustainable growth and external viability indeed, there is the need for a change in the policy focus and movement to the industrialization sector (Oyetade, Shri \& Nor, 2016).

\section{Manufacturing Capacity Utilization}

Capacity utilization rate plays a crucial role in evaluating economic performance of manufacturing firms. Capacity utilization is an important factor to be considered when an increase in productivity and expansion of a firm's production become necessary. Also, the need to consider capacity utilization is vital in many developing countries especially in Nigeria where capital is very scarce and mostly underutilized (Adeyemi \& Olufemi, 2016). According to Afroz and Roy as cited in Okunade, (2018), theory of economies of scale stipulates that a cost-minimizing firm has a tendency to increase the utilization of its capital if the returns to scale decreases as its production increases, that is, the rate of capacity utilization could be determined endogenously. Thus, the rate of capacity utilization remains an important concept, though often neglected, in the production process because the presence of idle resources that can be readily engaged in production activities constitute a big problem in explaining fluctuation in firm output in Nigeria where underutilization of some productive equipment have become rampant in almost all productive firms. Though, underutilization of resources in productive firms is not only peculiar to Nigerian firms.

\section{Relationship between Non-Oil Exports and Economic Growth}

Economic development is one of the main objectives of every society in the world and economic growth is fundamental to economic development (Anwer as cited in Alam \& Myovella, 2016). There are many contributing factors to economic growth. Firstly, Export is considered as one of the very important factors among them. Export have been considered as growth-enhancing within the traditional development literature, based on the suggested positive productivity spillover from the tradable to the non-tradable sector (Madsen, 2009). Secondly, foreign exchange from exports can be used to finance imported manufactured and capital goods and technology, which contribute to growth (Grossman, 1991). Thirdly, Alam 
and Myovella (2016) argues that the export sector in a country is by nature competitive for its existence in the global arena. This competition leads to scale economies, technological progress, and eventually growth. He further argues that, combining the international market with the domestic market facilitates larger-scale operations than does the domestic market alone. Fourth, the export sector creates positive externalities, such as more efficient management and production techniques, which lead to further growth. In the long run, exports may affect growth by availing of economies of scale, introducing incentives for improving the quality of the products, reducing inefficiencies and finally, innovating new technology due to competition in the world market.

\section{Exportation as a Tool for Economic Growth}

Exports play a vital role in the growth of any economy just as Ricardo as cited in Ewubare, Ajie and Ojiya (2017) pointed out that foreign trade is highly beneficial to a nation. Also, as observed by Singh (2010), trade is one of the several catalysts of productivity and growth and hence its contribution is contingent on its weight in the aggregate economic activity. The knowledge of this has helped many nations achieve economic growth and development. In light of this, the Nigerian economy left import substitution policies for the export promotion strategies or export-led growth approach. Export promotion strategies or export-led growth approach. Export promotion strategies are policies that encourage exports, often through the free movement of capital, workers, enterprises and students; a welcome to multinational corporations; and open communications (Todaro \& Smith, 2011).

As early as the 1970s, studies were published showing that developing countries that pursued an export-led approach experienced far more rapid economic growth as did countries with protectionist policies. The original four Tigers (Hong Kong, Taiwan, Singapore and South Korea) were the subject of most of this early research, but the second wave of Asian newly industrialized countries or NICs (Indonesia, Thailand, Malaysia, and China) has also been very successful in pursuing export markets. As a result, these countries have grown rapidly. India, Mexico, and Brazil could be added as recent converts to this approach. Dunn \& Mutti, (2004). found out that exports of goods and services represent one of the most important sources of foreign exchange income that ease the pressure on the balance of payments and create employment opportunities. Ewubare, Aije and Ojiya, (2017) while acknowledging Frankel and Romer (1999) notes that trade increases GDP which ultimately increases the income per person. In other words, trade not only enhances economic growth but is also a useful tool in achieving economic development provided there are other structural and institutional changes in the economy.

\section{Performance of Non-Oil Export Products in Nigeria}

Before crude oil came into prominence in the middle of the 1970s, primary export commodities dominated the export sector. However, since the late 1970s crude oil has become conspicuously dominant. In the period 1980 to 1985, crude oil exports constituted about 93.0 percent of total exports which increased to 96.0 percent in 1986 to 1998, conversely, the share of non-oil export of the total, declined from 7.0 percent in the period 1970-1985 to 4.0 percent between 1986 and 1998. Within, the non-oil exports as a proportion of total non-oil exports averaged 61.1 percent. During the period 1981-1987, its share declined to about 30.0 percent. The share of cocoa in total export increased slightly, about 5.0 percent between 1986 and 1987. By 2015, the percentage of cocoa in non-oil exports was $21 \%$ making it the highest agricultural product 
exported in Nigeria (CBN, 2016) owing largely to the liberalization of trade and exchange rate. Although non-oil performance remained largely unimpressive, a remarkable development is the expansion of non-oil exports to include non-traditional commodities such as shrimps, cotton, yam, pineapple, etc.

In the manufacturing sub-sector, items currently exported include aluminum products, asbestos products, soaps and detergents, textiles, chemical, beer, empty bottles, carpet/rug and beverages among others. The non-oil export sector is expanding though slowly, to include non-traditional items such as notable development has been the disappearance of some traditional exports such as palm oil, groundnuts. Ginger and hides and skins. Furthermore, the international demand for non-oil products remained low due largely to the development of synthetic alternatives, discriminatory tariffs and the new entrants into the international commodity market. Manufacturing exports have remained low implying that there has not been any significant shift from the primary sector to the industrial sector. In value terms, Nigeria's total exports, on the average, stood below $\$ 500$ million in the 1960 s. During the 1970s, the export figure rose, averaging $\$ 2,2373$ and $₹ 2,242.3$ million in 1970-1974 and 1975-1979, respectively, the substantial rise in export earnings was attributable to enhanced receipts from crude oil exports. There was a sharp increase in the export price of crude petroleum before it fell steadily to $\$ 311,026.4$ and $\$ 7,502.6$ million in 1982 and 1983 respectively.

The value of total exports fluctuated upwards to a peak of $218,770.1$ million in 1993, dropped in 1994 and later rose steadily to 1, 309,543 million in 1996. The improved performance of the export sector in the last two years is traceable to the impact of the depreciation of the exchange rate of the naira and increase in the export price of petroleum. The upward trend was, however, reversed in 1997 and 1998 with total exports declining to 1 1, 212, 449.4 and \$717,786.5 million respectively. Under the Structural Adjustment Programme (SAP) introduced in 1986 export promotion incentives were targeted at non-oil export. This group of exports rose from $\$ 532$ million to $\$ 8,349.0$ million and $\$ 20,102.5$ million in 1994 and 1995 respectively. Exchange rate depreciation pursued under SAP represents the principal factor explaining the rapid expansion in the value of export, as the dollar value of non-oil export declined from 613 million US Dollar to 244 million between 1988 and 1992. Agricultural export also rose in naira value from $\$ 407$ million naira in 1986 through $\$ 2,429.3$ million in 1990 to $13,431.1$ million in 1995 , the contribution of non-oil export to the total export climbed from about $6.25 \%$ in 1986 to 8.8 percent. Thereafter, the relative share of non-oil exports has been recording a positive growth rate of $9.6 \%$. This is an improvement from what obtained in the oil boom era and late 1980s. However, the growth rate of non-oil export is less than encouraging apart from 1987, 1988-1991 and year 2000 in which growth rate was higher as $20 \%$ for the period under study (CBN 2016).

It would be noted that the relatively impressive growth rate recorded in certain years would be linked to the depreciation in the value of naira in those years. The average annual growth rate of non-oil exports was about $24.8 \%$ in 1985 and in 2001. The decline in the average growth rate of non-oil exports in the world oil market export of unprocessed agricultural commodities with little value-added account for the bulk of non-export earnings in spite of various diversification programmes implemented. The structure of non-oil export shows that the share of manufacture increased substantially from 2.9 percent in 1987 to 23.8 percent in 1992 after which it declined, the total export was insignificantly increased from 0.2 percent in 1987 to 0.9 
percent in 1991 and then decreased to 0.6 percent in 1995. However, by 2016, non-oil exports have increased to $\$ 10,563,200$ million (CBN, 2016).

\section{Theory of Comparative Advantage}

The theory of comparative advantage propounded by the British economist David Ricardo in 1817 is the core theory for free trade. According to Ian (1990), all the myriad things we are told about free trade is good for us are boiled down to hard economics and weighed against the costs by this theory and its modern ramifications. If this theory is true, no matter how high the costs of free trade, we can rely upon the fact that in any economy there are reaping benefits that exceed the costs. David Ricardo stated his theory that a country has a comparative advantage in producing goods if the opportunity cost of producing those goods, in terms of other goods, is lower in that country than it is in other countries. Ricardo's theory of comparative advantage creates hope for technologically backward countries by implying that they can be a part of the world trading system even though their labour productivity in every good may be lower than that in the developed countries. In the Ricardian model, trade is a winwin situation, as workers in all trading countries are able to consume more of all goods.

The theory of comparative advantage thus sees international trade as a vast interlocking system of trade-offs, in which nations use the ability to import and export to shed opportunity costs and reshuffle their factors of production to their most valuable uses. And this all happens automatically because if the owners of some factors of production find one more valuable use for it they will find it profitable to move to that use. Robert (2005) argues that the primary economic objective of a nation is to generate a high and increasing standard of living for its people. The achievement of attaining this goal depends on high productivity of its employed resources. No nation can be competitive and a net exporter of everything. Because the nation's stock of resources is limited, the ideal is for these resources to be used in their most productive manner. By applying the concept of this theory, Nigeria could produce and export agricultural products which are not in primary form but which are processed and added value.

\section{Empirical Review}

Fiwe and Turakpe (2017) carried out comparative analysis on the role of crude oil export and non-oil export in relation to Nigeria's economic growth. Data were collected from CBN statistical bulletin from 1980-2015. OLS, Augmented dickey fuller, co-integration and error correction model were used to analyse the data. Findings suggested that both the oil export sector and non oil export sector have a positive impact on GDP. The error correction model indicated that oil export sector and non oil export sector has a long run relationship with Nigeria's GDP. It concludes that non-oil export has greater impact on the economy than the oil export sector for the period under reviewed.

Ewetan, Fakile, Urhie and Oduntan (2017) examined the long run relationship between agricultural output and economic growth in Nigeria for the period 1981 to 2014 using time series data. Results from Johansen maximum likelihood co-integration approach and Vector error correction model supported evidence of long run relationship between agricultural output and economic growth in Nigeria.

Ewubare, Ajie and Ojiya (2017) examined the impact of non-oil exports on economic growth in Nigeria through 1980 to 2015 using annual time series data derived from Central Bank of Nigeria's statistical bulletin (CBN) and World Development Indicators (2015). Autoregressive 
Distributed Lags (ARDL) econometric technique and other econometric tools were used. ARDL Bounds Co integration test revealed that the variables are co-integrated which confirms the existence of long-run equilibrium relationship between the variables. Granger causality test indicated the presence of casual relationship among the variables in the model. The findings show that non-oil exports have performed below expectations giving reasons to doubt the effectiveness of the sector and export promotion strategies that have been adopted in the Nigerian economy.

Ugwu (2017) empirically investigated the impact of some selected non-oil exports on Nigerian economy during the period of 1986-2015. This study was carried out against the background of the crucial role non-oil export can play as an alternative source of revenue apart from crude oil exports. In carrying out the analysis, multiple regressions were employed to analyse data on such variables; Gross Domestic Product (GDP)- as proxy for economic growth, Non-oil exports (NOE), Oil Export (OEX), and Government Expenditure (GEX). The result showed that the Non-oil exports and its associated Revenue from non-oil sectors products has a positive impact on Nigeria's' Economic Growth and Development.

Ugwuegbe and Uruakpa (2013) employed OLS to determine the impact of oil and non-oil export on economic growth while granger causality test was employed to determine the direct casualty between the variables under consideration. Correlation analysis was also deployed to determine the degree of relationship between the variables and the result showed that all the variables are highly correlated. The study uses annual time series data from 1986-2011, obtained from the Central Bank of Nigeria (CBN) statistical bulletin. The study revealed that oil export has a positive and significant impact on economic growth in Nigeria proxied by GDP, Non-oil export was also found to be positively and significantly impacting to economic growth in |Nigeria is proxied by GDP.

\section{Summary of Literature}

The role of non-oil exports in economic growth of developing countries cannot be over emphasized. It is argued that sustained and increased non exports increases the value of the exporting country's currency owing to foreign exchange from exports. The majority of the literature reviewed provided evidence on the positive effect of non-oil exports on economic growth of both developed and developing countries. However, little literature gave insight on the insignificant effect on non-oils' exports on economic growth, especially for developing countries that have large deposits of crude oil like Nigeria. In the studies on the connection between non-oil exports and economic growth, scholars adopted various econometric tools such as granger causality test, Johansen co-integration, vector error correction model and Gregory and Hansen (1996) co-integration test among others to make their conclusion.

\section{METHODOLOGY}

\section{Research Design}

An ex-post facto research design was adopted to ascertain the effect of non-oil exports on economic growth in Nigeria. In this type of research design, the researcher cannot manipulate the variation in the variables as their existing data is available and published by government 
agencies (Raj \& Chand, 2017). The time frame of thirty three (33) years, from 1986 to 2018 allows for a large number of observations which will improve the robustness of the results.

\section{Sources of Data}

The secondary data as applied in this study were obtained from the Central Bank of Nigeria (CBN) statistical bulletin of 2017. The data as published in the statistical bulletin were on yearly basis except otherwise stated. The data were on an annual basis as contained in the Central Bank of Nigeria (CBN) statistical bulletin.

\section{Description of Variables}

The dependent variables are Growth Rate of Real Gross Domestic Product (GRRGDP) Agricultural Contribution to Real Gross Domestic Product (ACRGDP) and Manufacturing Capacity Utilization (MCU). Non-Oil Exports (NOEXP) is the independent variable which is the value of the total non-oil exports earnings by Nigeria.

GRRGDP is growth rate of real gross product: The growth rate of gross domestic product captures the changes in gross domestic product over time, if the economy grows, it will be positive but if it does not, then it will be negative which implies recession. Moshen (2015) and Shahbaz, Ahmad and Asad (2010) utilized this proxy of economic growth.

ACR GDP is agricultural contribution to real gross domestic product: This measures the proportion of the real gross domestic income that is accounted for by the agricultural sector. Mustapha, Akintuotu, Shiro and Yusuf (2013) used this variable.

MCU is manufacturing capacity utilization: This implies the ratio of actual output to the level of optimum output beyond which the average cost of production begins to rise. That is manufacturing capacity utilization expresses output as a percentage of total potential output.

NOEXP is non-oil exports: Non-oil exports are products, which are produced within the country in the agricultural, mining, quarrying and industrial sector that are sent outside the country to generate revenue for the growth of the economy, excluding oil products. Non-oil exports were used by Fiiwe and Turakpe (2017), Olajide, Akinlabi and Tijani (2012), Ogunjimi, Aderinto and Ogunro (2015) among others.

\section{Model Specification and Validity}

Model specification is the mathematical expression of the dependent and explanatory variables in a model. A modified model of Moshen (2015) for a study in Namibia was adapted. The functional form of Mohsen (2015) is expressed as:

\section{$\operatorname{LnGDP}=a_{o}+\square_{1} \ln O x+\square_{2} \ln \mathrm{NOX}+\square_{t}$}

Where: $\boldsymbol{a}_{\boldsymbol{o}}$ is the intercept; $\square_{\mathbf{1}}$ and $\square_{\mathbf{2}}$ are the slope coefficient of the model; $\mathbf{L n G D P}$ is the natural $\log$ of real gross domestic product, $\ln N \boldsymbol{O X}$ is the natural $\log$ of real gross domestic product; $\ln N O X$ is the natural $\log$ of real non-oil exports, and $\square_{t}$ is the error term. Modifying the model in ascertaining the effect of non-oil exports on growth rate of real gross domestic product, agricultural contribution to real gross domestic product and manufacturing capacity utilization, the functional model below were stated: 


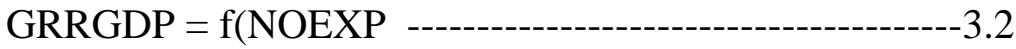

$$
\begin{aligned}
& \text { ACRGDP = f(NOEXP) ---------------------------------------3.3 }
\end{aligned}
$$

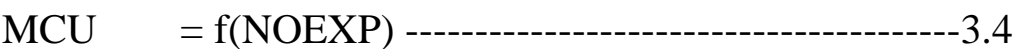

Equation 3.2 and 3.3 were not logged as there were already in the same numerical base (N" million), while Equ. 3.4 was logged to ensure that manufacturing capacity utilization which is percentage comes to terms with the values of non-oil exports. Thus:

$$
\begin{aligned}
& \text { Model 1; GRRGDP } P_{t}=a_{o}+\square{ }_{1} N O E X P_{t}+\square t \\
& \text { Model 2; ACRGDP } P_{t}=a_{o}+\square_{1} N O E X P_{t}+\square t \\
& \text { Model 3; } \operatorname{LogMCU} \mathrm{t}=a_{o}+\square_{1} N O E X P_{t}+\square_{t}
\end{aligned}
$$

Where:

GRRGDP is the growth rate of real gross domestic product,

ACRGDP is agricultural contribution to real gross domestic product,

MCU is manufacturing capacity utilization,

NOEXP is non-oil exports, $a_{o}$ is the coefficient of the constant $\square_{1}$ is the slope coefficient of the model, and $\square$ is the error term.

\section{Techniques for Data Analysis}

The hypotheses and research questions were the basis for presenting the data analyzed. The Ordinary Least Square (OLS) estimation technique was applied in guesstimating the models. $\mathrm{E}$ - views 9.0 was the econometric software used for the analysis.

\section{Unit Root}

The variables were diagnosed for unit root to ensure that they are not hampered by stationary defects which most data possess which may likely affect the robustness of results. The Augmented Dicky-Fuller (ADF) and Philips-Perron tests were used to check the stationarity of the variables. To reject, the p-value of the ADF statistics must be significant at $5 \%$ level of significance, however, $5 \%$ level of significance is accepted by checking the p-value of the variable concerned.

\section{Johansen co-integration test}

To determine the number of co-integrating question equation (s) between the dependent and explanatory variables, the Johansen co-integration was utilized. The Johansen co- integration offers two tests: the trace test and the eigenvalue test to the number of co-integrating equation (s). The presence or absence of a long run relationship between the variables concerned gives room for testing the impact of one variable or the other. 


\section{Econometric Statistics}

The results were interpreted using econometric statistical criteria which include Adjusted RSquare, F-Statistic and Durbin Watson test of autocorrelation. These statistical criteria are required for inferences in a model to be statistically reliable and accepted.

Adjusted Coefficient of Determination (R2): This determines the changes in the dependent variables attributed to variation in the independent variable (s). The higher the $\mathrm{R} 2$ the greater the explaining power of the explanatory variable (s). The value of R2 lies between zero and one, i.e., $0<\mathrm{R} 2>1$ with values close to 1 indicating a good degree of fit. F- Statistics: The Fstatistics assesses whether or not the changes in the dependent variable significantly explained the influences or variation in the independent variable (s). If the p-value of F-values significantly is less than $5 \%$, then the independent variable (s) significantly explains the changes in the dependent variable. The reverse is the case if the p-value of the F-statistic is less than 5\%. Durbin Watson Statistics: The Durbin-Watson statistic is used to ascertain whether the variables in the model are serially correlated. The benchmarks for no autocorrelation 2.0. However, Durbin-Watson statistics value that is quite close to $\quad 2.0$ would accept as evidence that the variables are not serially correlated.

\section{A Priori Expectations}

This is the expected relationship that should exist between and or among the dependent or independent variables of the model based on the assumption of the law of comparative advantage. Non - oil exports is expected to relate positively with growth rate of real gross domestic product, agricultural contribution to real gross domestic product and manufacturing capacity utilization. The observed sings of the independent variable will be interpreted on the supposed footprint of law of comparative advantage. Table 1 shows the expected signs of the independent variable in the model.

Table 1: Supposed Sign of Independent Variable

\begin{tabular}{llc}
\hline Symbol & Variable & Expected Signs \\
\hline NOEXP & Non-Oil Exports & + \\
\hline
\end{tabular}

Source: Researcher's Assumption based on the Law of Comparative Advantage

\section{DATA ANALYSIS}

\section{Presentation of Data}

The data from the Central Bank of Nigeria (CBN) statistical bulletin used in estimating the models are presented in the section. Growth rate of real gross domestic product, agricultural contribution to real gross domestic product, manufacturing capacity utilization and corresponding data on non-oil exports from 1986 to 2018 are presented in Table 2.

Table 2: Real Gross Domestic Product, Growth Rate of Real Gross Domestic Product, Agricultural Contribution to RGDP, Manufacturing Capacity Utilization and Non-Oil Exports from 1986-2018 


\begin{tabular}{|c|c|c|c|c|c|}
\hline Year & $\begin{array}{l}\text { Real Gross } \\
\text { Domestic } \\
\text { Product } \\
\text { (\#'Billion) }\end{array}$ & $\begin{array}{l}\text { RGDP } \\
\text { Growth } \\
\text { Rate }(\%)\end{array}$ & $\begin{array}{l}\text { Agricultural } \\
\text { RGDP } \\
\text { (\$'Million) }\end{array}$ & $\begin{array}{l}\text { Manufacturing } \\
\text { Capacity } \\
\text { Utilization (\%) }\end{array}$ & $\begin{array}{l}\text { Non-Oil } \\
\text { Exports } \\
\text { ('Million) }\end{array}$ \\
\hline 1986 & $15,237.99$ & -8.75 & $2,986,840.00$ & 38.80 & 600.00 \\
\hline 1987 & $15,263.93$ & -10.75 & $2,891,670.00$ & 40.40 & $2,200.00$ \\
\hline 1988 & $16,215.37$ & 7.54 & $3,174,570.00$ & 42.40 & $2,800.00$ \\
\hline 1989 & $17,294.68$ & 6.47 & $3,325,950.00$ & 43.80 & $3,000.00$ \\
\hline 1990 & $19,305.63$ & 12.77 & $3,464,720.00$ & 40.30 & $3,300.00$ \\
\hline 1991 & $19,199.06$ & -0.62 & $3,590,840.00$ & 42.00 & $4,700.00$ \\
\hline 1992 & $19,620.19$ & 0.43 & $3,674,790.00$ & 38.10 & $4,200.00$ \\
\hline 1993 & $19,927.99$ & 2.09 & $3,743,670.00$ & 37.20 & $5,000.00$ \\
\hline 1994 & $19,979.12$ & 0.91 & $3,839,680.00$ & 30.40 & $5,300.00$ \\
\hline 1995 & $20,353.20$ & -0.31 & $3,977,380.00$ & 29.29 & $23,100.00$ \\
\hline 1996 & $21,177.92$ & 4.99 & $4,133,550.00$ & 32.46 & $23,300.00$ \\
\hline 1997 & $21,789.10$ & 2.80 & $4,305,680.00$ & 30.40 & $29,200.00$ \\
\hline 1998 & $22,332.87$ & 2.72 & $4,475,240.00$ & 32.40 & $34,100.00$ \\
\hline 1999 & $22,449.14$ & 0.47 & $4,703,640.00$ & 34.60 & $19,500.00$ \\
\hline 2000 & $23,688.28$ & 5.32 & $4,840,970.00$ & 36.10 & $24,800.00$ \\
\hline 2001 & $25,267.54$ & 4.41 & $5,024,540.00$ & 42.70 & $28,000.00$ \\
\hline 2002 & $28,957.71$ & 3.79 & $7,817,080.00$ & 54.90 & $94,700.00$ \\
\hline 2003 & $31,709.45$ & 10.35 & $8,364,830.00$ & 56.50 & $94,800.00$ \\
\hline 2004 & $35,020.55$ & 33.74 & $8,888,570.00$ & 55.70 & $113,600.00$ \\
\hline 2005 & $37,474.95$ & 3.45 & $9,516,990.00$ & 54.80 & $106,000.00$ \\
\hline 2006 & $39,995.50$ & 8.21 & $10,222,470.00$ & 53.30 & $133,600.00$ \\
\hline 2007 & $42,922.41$ & 6.83 & $10,958.470 .00$ & 53.38 & $199,300.00$ \\
\hline 2008 & $46,012.52$ & 6.27 & $11,645,370.00$ & 53.84 & $525,900.00$ \\
\hline 2009 & $49,856.10$ & 6.93 & $12,330,330.00$ & 55.14 & $500,900.00$ \\
\hline 2010 & $54,612.26$ & 7.84 & $13,048,890.00$ & 56.22 & $711,000.00$ \\
\hline 2011 & $57,511.04$ & 4.89 & $13,429,390.00$ & 57.35 & $913,500.00$ \\
\hline 2012 & $59,929.89$ & 4.28 & $14,329,710.00$ & 58.85 & $879,300.00$ \\
\hline 2013 & $63,218.72$ & 5.39 & $14,750,520.00$ & 57.99 & $1,130,200.00$ \\
\hline 2014 & $67,152.79$ & 6.31 & $15,380,390.00$ & 60.50 & $953,500.00$ \\
\hline 2015 & $69,023.93$ & 2.70 & $15,952,220.00$ & 54.90 & $660,700.00$ \\
\hline 2016 & $67,931.23$ & -1.61 & $16,607,340.00$ & 51.40 & $656,800.00$ \\
\hline 2017 & $68,490.98$ & 0.82 & $17,179,570.00$ & 56.28 & $1,074,900.00$ \\
\hline 2018 & $69,810.02$ & 0.74 & $17,544,150.00$ & 55.84 & $1,434,200.00$ \\
\hline
\end{tabular}

Source: Central Bank of Nigeria (CBN) Statistical Bulletin, 2018

\section{Growth Rate of Real Gross Domestic Product}

The growth rate of real gross domestic product was $-8.75 \%$ in 1986, which later rose to $7.80 \%$ by the end of 2010. The growth rate of real gross domestic product has continued to appreciate from 2010 to 2012. From 1986 to 2000, as shown in Table 2, the growth rate of gross domestic product gradually rose from $-8.75 \%$ to $5.32 \%$ in 2000 . 


\section{Agricultural Contribution to Real Gross Domestic Product}

Agricultural contribution to real gross domestic product in 2009 was $\$ 3,464,720$ million, a rise of $4.01 \%$ from $\$ 3,325,950$ million in 2008. In 2012, agricultural contributions to real gross domestic product increased to $14,329,710$ million. As can be seen from table 2, from 1986 to 2018 there has been steady increase in agricultural contribution to real gross domestic product.

\section{Manufacturing Capacity Utilization}

Manufacturing capacity utilization in 2005 was 54.80, a decrease of $1.64 \%$ from 55.70 in 2004. In 2010, manufacturing capacity utilization increased by $1.92 \%$ to 56.22 . as shown in table 2 , from 1991 to 1995 manufacturing capacity utilization was 61.40 compared to 54.90 in 2015 .

\section{Non-oil Exports}

Table 2, revealed that the trend in non-oil exports during the period 1986 to 2018 changed considerably, changing from $\$ 600$ million to $\$ 656,800$ an appreciation of over $1,000 \%$. The exchange rate at the end of the year 2009 reached $\$ 500,900$ million compared to $\$ 525,900$ million in 2008. The year 2011 mark the highest record in non-oil exports as it was valued at N1,130,200 million

\section{Descriptive Properties of the Data}

The descriptive properties of the data are presented in Table 3. The mean of the data are 4.51 for GRRGDP, 7916010 for ACRGDP, 46 for MCU and 25440.5 for NOEXP, while the median are 4.41, 5024540, 43.80 and 34100 for GRRGDP, ACRGDP, MCU and NOEXP respectively. The maximum and minimum values are 33.74 and -10.75 for GRRGDP, 16607340 and 2891670 for ACRGDP, 60.50 and 29.29 for MCU and 1130200 and 600.0 for NOEXP.

The standard deviations of the data are 7.24, 4685336, 10.23 and 355586.9 for GRRGDP, ACRGDP, MCU and NOEXP respectively. Only MCU that was not positively skewed towards normality. The kurtosis value shows that the data are not leptokurtic in nature as evidenced by the Kurtosis statistics which are less than three for all the variables. However, the data were normally distributed as revealed by the significant $\mathrm{p}$-values for all the data. This is to say that the data follow normal distribution.

Table 3: Data Descriptive Properties

\begin{tabular}{|c|c|c|c|c|c|c|c|c|c|c|}
\hline & Mean & Median & $\begin{array}{l}\text { Maximu } \\
\text { m }\end{array}$ & \begin{tabular}{|l|} 
Minimu \\
m
\end{tabular} & Std..Dev & Skewness & Kurtosis & $\begin{array}{l}\text { Jarque- } \\
\text { Bera }\end{array}$ & P-value &. Obs \\
\hline GRRGDP, & 4.511613 & 4.41000 & 33.74000 & -10.75000 & 7.239939 & & 10.33930 & 84.94628 & 00000 & 33 \\
\hline ACR & 7916010 & $\mathbf{5 0 2 4 5 4 0}$ & 16607340 & 2891670. & 4685336 & 0.505912 & 1.716220 & 6.451177 & 0.038068 & 33 \\
\hline MCU & 46.80000 & 43.80000 & 60.50000 & 29.29000 & 10.22572 & -0.191127 & 1.520361 & 5.016622 & 0.041283 & 33 \\
\hline NOEXP & 254406.5 & 34100.00 & 11.30200 & 600.0000 & 355586.9 & 1.178870 & 2.868898 & 7.202499 & 0.027290 & 33 \\
\hline
\end{tabular}

Source: Output data from E-views 9.0 


\section{Diagnostic Test Result}

\section{Serial Correlation LM Test}

The essence of the serial correlation LM test is to test for the presence of autocorrelation in a model. The null hypothesis of LM is that there is no serial correlation up lag order 2 . The pvalues of the Breusch-Godfrey serial correlation test in Table 4 are insignificant at 5\%, an inference that the variables in the model are not serially correlated.

Table 4: Breusch-Godfrey Serial Correlation LM Test

\begin{tabular}{|l|l|l|}
\hline Models & F-statistic & P-value \\
\hline Model 1 & $\mathbf{1 . 5 8 2 2 2 1}$ & $\mathbf{0 . 2 2 5 4}$ \\
\hline Model 2 & $\mathbf{0 . 0 1 8 0 1 0}$ & $\mathbf{0 . 9 8 2 2}$ \\
\hline Model 3 & $\mathbf{0 . 4 8 3 3 7 3}$ & $\mathbf{0 . 6 2 2 8}$ \\
\hline
\end{tabular}

Source: Computer analysis using E-views 9.0

Heteroskedasticity Test

Classical econometric assumption states that a model should be free from the problem of heteroscedasticity. The probability of the Chq. Statistics for the models are insignificant at $5 \%$ level of significance, suggesting that there is no heteroskedasticity in the models. Test of heteroskedasticity for the models is presented in Table 5.

Table 5: Heteroskedasticity Test

\begin{tabular}{|l|l|l|}
\hline Models & F-statistic & P-value \\
\hline Model 1 & $\mathbf{0 . 6 0 3 1 9 2}$ & $\mathbf{0 . 5 5 4 3}$ \\
\hline Model 2 & $\mathbf{0 . 1 7 9 7 1 2}$ & $\mathbf{0 . 8 3 6 5}$ \\
\hline Model 3 & $\mathbf{1 . 4 8 0 2 2 0}$ & $\mathbf{0 . 2 4 4 0}$ \\
\hline
\end{tabular}

Source: Computer analysis using E-views 9.0

\section{Ramsey RESET Test}

The essence was to ascertain if non-linear combinations of the independent variables have any power in explaining the dependent variable or not. If the dependent variable is explained by the non-linear combinations of the independent variables, the model is not well specified. The insignificant at $5 \%$ level of significance of p-values of the t-statistics as in Table 6 shows that the models were well specified.

Table 6: Ramsey RESET Test

\begin{tabular}{|l|l|l|l|}
\hline Models & Value & df & P-value \\
\hline Model 1 & $\mathbf{1 . 6 3 5 7 3 3}$ & $\mathbf{2 6}$ & $\mathbf{0 . 1 1 3 9}$ \\
\hline Model 2 & $\mathbf{1 . 3 7 7 3 1 7}$ & $\mathbf{2 6}$ & $\mathbf{0 . 1 8 0 2}$ \\
\hline Model 3 & $\mathbf{1 . 0 . 4 1 0 7 0}$ & $\mathbf{2 4}$ & $\mathbf{0 . 3 0 8 2}$ \\
\hline
\end{tabular}

Source: Computer analysis using E-views 9.0 


\section{Stationarity Test Result}

Augmented Dickey-Fuller (ADF) and Philips Perron (PP) tests were used to check for stationarity of data to ensure that the variables are from a stationarity defect linked with most time series data. The ADF and PP results in Table 7 and 8 shows that all the variables are stationary at first difference as such, inferences made from analysis will not be spurious.

Table 7: ADF Test Result

\begin{tabular}{|c|c|c|c|c|}
\hline Variables & $\begin{array}{ll}\text { ADF } & \text { Test } \\
\text { Statistic } & \end{array}$ & $\begin{array}{l}\text { Test Critical } \\
\text { Value at } 1 \%\end{array}$ & $\begin{array}{l}\text { Test Critical } \\
\text { Value at 5\% }\end{array}$ & $\begin{array}{l}\text { Order of } \\
\text { Integration Remark }\end{array}$ \\
\hline GRRGDP & $-7.992384(0.00) *$ & -3.679322 & -2.967767 & 1(1)/Stationary \\
\hline ACRGDP & $-4.513452(0.00) *$ & -3.679322 & -2.967767 & 1(1)/Stationary \\
\hline MCU & $-3.649944(0.01)^{*}$ & -3.679322 & -2.967767 & 1(1)/Stationary \\
\hline NOEXP & $-3.364737(0.02)^{*}$ & -3.752946 & -2.998064 & 1(1)/Stationary \\
\hline
\end{tabular}

Source: Computer analysis using E-views 9.0

Table 8: PP Test Result

\begin{tabular}{|c|c|c|c|c|}
\hline Variables & PP Test Statistic & $\begin{array}{l}\text { Test Critical } \\
\text { Value at } 1 \%\end{array}$ & $\begin{array}{l}\text { Test Critical } \\
\text { Value at 5\% }\end{array}$ & $\begin{array}{l}\text { Order of } \\
\text { Integration Remark }\end{array}$ \\
\hline GRRGDP & $-10.20593(0.00)^{*}$ & -3.679322 & -2.967767 & 1(1)/Stationary \\
\hline ACRGDP & $-4.520396(0.00) *$ & -3.679322 & -2.967767 & 1(1)/Stationary \\
\hline MCU & $-3.658280(0.01)^{*}$ & -3.679322 & -2.967767 & 1(1)/Stationary \\
\hline NOEXP & $-4.838775(0.00) *$ & -3.679322 & -2.967767 & 1(1)/Stationary \\
\hline
\end{tabular}

Source: Computer analysis using E-views 9.0

\section{Long Run Relationship}

The long run relationship was assessed using the Johansen co-integration technique. The traditional approach which is Johansen co-integration requires the data to be integrated at the same level before co-integration relationship is estimated. The stationary test performed proved that the data were integrated at the same order that is, order one 1 (1) which provides the basis for using the Johansen co-integration approach. Table 9 shows that there is a long run relationship between non-oil exports and growth rate of real gross domestic product in Nigeria. This is based on the argument that Trace test and Max-eigenvalue test indicates one (1) cointegrating equation at 5\% level of significance. By implication, increased non-oil export earnings will contribute in no small measure to growth of Nigeria's real gross domestic product. Table 10 and 11 prove that agricultural contribution to real gross domestic product, manufacturing capacity utilization and non-oil exports were not related in the long run. 
Table 9: Johansen Co-integration for GRRGDP and NOEXP

\begin{tabular}{|c|c|c|c|c|}
\hline \multicolumn{5}{|c|}{ Unrestricted Co-integration Rank Test (Trace) GRRGDP and NOEXP } \\
\hline $\begin{array}{l}\text { Hypothesized } \\
\text { Number of CE(s) }\end{array}$ & Eigen Value & Trace Statistic & $\begin{array}{ll}0.05 & \text { Critical } \\
\text { value } & \end{array}$ & Prob. $\approx \approx$ \\
\hline $\begin{array}{l}\text { None* } \\
\text { At most } 1\end{array}$ & $\begin{array}{l}0.407957 \\
0.026966\end{array}$ & $\begin{array}{l}15.99386 \\
0.792753\end{array}$ & $\begin{array}{l}15.49471 \\
3.841466\end{array}$ & $\begin{array}{l}0.0420 \\
0.3733\end{array}$ \\
\hline \multicolumn{5}{|c|}{$\begin{array}{l}\text { Unrestricted Co-integration Rank Test (Maximum Eigenvalue) GRRGDP anc } \\
\text { NOEXP }\end{array}$} \\
\hline $\begin{array}{l}\text { Hypothesized } \\
\text { Number of CE(s) }\end{array}$ & Eigen Value & $\begin{array}{l}\text { Maximum } \\
\text { Eigen Statistic }\end{array}$ & $\begin{array}{|ll|}0.05 & \text { Critical } \\
\text { value } & \\
\end{array}$ & Prob. $\approx \approx$ \\
\hline $\begin{array}{l}\text { None* } \\
\text { At most } 1\end{array}$ & $\begin{array}{l}0.407957 \\
0.026966\end{array}$ & $\begin{array}{l}15.20110 \\
0.792753\end{array}$ & $\begin{array}{l}14.26460 \\
3.841466\end{array}$ & $\begin{array}{l}0.0355 \\
0.3733\end{array}$ \\
\hline
\end{tabular}

Trace test and Max-eigenvalue test indicate one (1) co-integration at the 0.05 level: $*$ denotes

Rejection of the hypothesis at the 0.05 level;**MacKimon-Haug-Michelis (1999) p-values

Table 10: Johansen Co-integration for ACRGDP and NOEXP

\begin{tabular}{|c|c|c|c|c|}
\hline $\begin{array}{l}\text { Unrestricted Co } \\
\text { NOEXP }\end{array}$ & ration Ranl & est (Maximum & Eigenvalue) GR & RGDP \\
\hline $\begin{array}{l}\text { Hypothesized } \\
\text { Number of CE(s) }\end{array}$ & Eigen Value & $\begin{array}{l}\text { Maximum } \\
\text { Eigen Statistic }\end{array}$ & $\begin{array}{ll}0.05 & \text { Critical } \\
\text { value } & \end{array}$ & Prob. $\approx \approx$ \\
\hline $\begin{array}{l}\text { None* } \\
\text { At most } 1\end{array}$ & $\begin{array}{l}0.221201 \\
0.061854\end{array}$ & $\begin{array}{l}9.101699 \\
1.851642\end{array}$ & $\begin{array}{l}15.49471 \\
3.841466\end{array}$ & $\begin{array}{l}0.0361 \\
0.1736\end{array}$ \\
\hline
\end{tabular}

\section{Unrestricted Co-integration Rank Test (Maximum Eigenvalue) GRRGDP and} NOEXP

\begin{tabular}{|l|l|l|l|l|}
\hline $\begin{array}{l}\text { Hypothesized } \\
\text { Number of CE(s) }\end{array}$ & Eigen Value & $\begin{array}{l}\text { Maximum } \\
\text { Eigen Statistic }\end{array}$ & $\begin{array}{l}0.05 \quad \text { Critical } \\
\text { value }\end{array}$ & Prob. $\approx$ \\
\hline None* & 0.221201 & 7.250057 & 14.26460 & 0.4600 \\
At most 1 & 0.061854 & 1.851642 & 3.841466 & 0.1736 \\
\hline
\end{tabular}

Trace test and Max-eigenvalue test indicate one (1) co-integration at the 0.05 level: * denotes rejection of the hypothesis at the 0.05 level;**MacKimon-Haug-Michelis (1999) p-values

\begin{tabular}{|c|c|c|c|c|}
\hline $\begin{array}{l}\text { Unrestricted Co } \\
\text { NOEXP }\end{array}$ & ration Ran & st (Maximum & Eigenvalue) GI & RGDP \\
\hline $\begin{array}{l}\text { Hypothesized } \\
\text { Number of CE(s) }\end{array}$ & Eigen Value & $\begin{array}{l}\text { Maximum } \\
\text { Eigen Statistic }\end{array}$ & $\begin{array}{ll}0.05 & \text { Critical } \\
\text { value } & \end{array}$ & Prob. $\approx \approx$ \\
\hline $\begin{array}{l}\text { None* } \\
\text { At most } 1\end{array}$ & $\begin{array}{l}0.147349 \\
0.048727\end{array}$ & $\begin{array}{l}6.071428 \\
1.448670\end{array}$ & $\begin{array}{l}15.49471 \\
3.841466\end{array}$ & $\begin{array}{l}0.6871 \\
0.2287\end{array}$ \\
\hline
\end{tabular}


Table 11: Johansen Co-integration for MCU and NOEXP

\begin{tabular}{|l|l|l|l|l|}
\hline $\begin{array}{l}\text { Unrestricted Co-integration Rank Test (Maximum Eigenvalue) GRRGDP and } \\
\text { NOEXP }\end{array}$ & Eigen Value & $\begin{array}{l}\text { Maximum } \\
\text { Eigen Statistic }\end{array}$ & $\begin{array}{l}0.05 \quad \text { Critical } \\
\text { value }\end{array}$ & Prob. $\approx$ \\
Number of CE(s) & & 4.622758 & 14.26460 & 0.6871 \\
None* & 0.147349 & 1.448670 & 3.841466 & 0.3733 \\
At most 1 & 0.048727 & & \\
\hline
\end{tabular}

Trace test and Max-eigenvalue test indicate one (1) co-integration at the 0.05 level: $*$ denotes rejection of the hypothesis at the 0.05 level;**MacKimon-Haug-Michelis (1999) p-values

\section{ARDL Regression}

The relationship between commercial banks' lending and economic development was tested using OLS regression techniques where the dependent variables were lagged for one year. The statistical criteria used in evaluating the regression result are coefficient of Adjusted R-square, F-statistic and Durbin Watson statistic.

\section{Non-Oil Exports and Growth Rate of Real Gross Domestic Product}

Table 12 reveals that there is a positive but insignificant relationship between non-oil exports and growth rate of real gross domestic product in Nigeria. Holding non-oil exports constant will result in a 3.8\% rise in growth rate of real gross domestic product. The Adjusted R-square reveals that $-6.11 \%$ variations in GRRGDP were due to changes in non-oil exports. The insignificant value (5\% significance level) of the F-statistic entails that non-oil exports did not significantly explain changes in GRRGDP within the period of the study. The Durbin Watson statistic of 2.0 unveils that there is no autocorrelation in the model.

Table 12: OLS regression of Non-Oil Exports and GRRGDP

\begin{tabular}{|l|l|l|l|l|}
\hline Variable & Coefficient & Std.Error & t-Statistic & Prob. \\
\hline GRRGDP(-1) & 0.234191 & 0.179148 & 1.307246 & 0.2022 \\
NOEXP & $1.63 \mathrm{E}-07$ & $3.63 \mathrm{E}-06$ & 0.044836 & 0.9646 \\
C & 3.806465 & 1.739188 & 2.188645 & 0.0374 \\
R-Square & 0.061105 & Mean dependent var & & 4.953667 \\
Adjusted R-Square & -0.008442 & S.D. dependent var & & 6.925139 \\
S.E.of regression & 6.954309 & Akaike info criterion & & 6.811240 \\
Sum squared resid & 1305.785 & Schwarz criterion & & 6.951359 \\
Log likelihood & -99.16859 & Hannan-Quinn criter & & 6.856065 \\
F-statistic & 0.878612 & Durbin - Watson stat & & 2.095838 \\
Prob (F-statistic & 0.426901 & & & \\
\hline
\end{tabular}

Source: Computer analysis using E-views 9.0 


\section{Non-Oil Exports and Agricultural Contribution to Real Gross Domestic Product}

The result in Table 13 shows that there is a positive relationship of non-oil exports and agricultural contribution to real gross domestic product. If non-oil exports are held constant, agricultural contribution to real gross domestic product would be $\$ 40,613.79$ million. A percentage increase in non-oil exports leads to a $0.4 \%$ rise in agricultural contribution to real gross domestic product. From the Adjusted R-square, non-oil exports caused 98.93\% changes in agricultural contribution to real gross domestic product. This is statistically significant as evidenced by the F-statistic and P-value of 1252.76 and 0.00 respectively. The Durbin Watson coefficient of 2.0 is the benchmark of no autocorrelation in a model.

Table 13: OLS Regression of Non-Oil Exports and GRRGDP

\begin{tabular}{|l|l|l|l|l|}
\hline Variable & Coefficient & Std.Error & t-Statistic & Prob. \\
\hline GRRGDP(-1) & 1.068000 & 0.049140 & 21.73402 & 0.0000 \\
NOEXP & 0.400151 & 0.613304 & 0.652452 & 0.5196 \\
C & 40613.79 & 255431.8 & 0.159001 & 0.8749 \\
R-Square & 0.989339 & Mean dependent var & & 8080315. \\
Adjusted R-Square & 0.988549 & S.D. dependent var & & 4673714. \\
S.E.of regression & 500132.4 & Akaike info criterion & & 29.17777 \\
Sum squared resid & $6.75 E+12$ & Schwarz criterion & & 29.31789 \\
Log likelihood & -434.6666 & Hannan-Quinn criter & & 29.22260 \\
F-statistic & 1252.758 & Durbin - Watson stat & & 2.013515 \\
Prob (F-statistic & 0.000000 & & & \\
\hline
\end{tabular}

Source: Computer analysis using E-views 9.0

\section{Non-Oil Exports and Manufacturing Capacity Utilization}

As can be seen in table 14, non-oil exports are positively but insignificantly related with manufacturing capacity utilization. When non-oil exports are held constant as revealed by the constant coefficient of 6.569069 , manufacturing capacity utilization would be $6.57 \%$. A unit increase in non-oil exports results in $2.75 \%$ appreciation in manufacturing capacity utilization. The Adjusted R-square shows that $89.20 \%$ changes in manufacturing capacity utilization were as a result of fluctuation in non-oil exports. This is statistically significant as depicted by the F-statistic and P-value of 78.12 and 0.00 respectively. The Durbin Watson value of 2.1 shows no autocorrelation in the model. 
Table 14: OLS Regression of Non-Oil Exports and GRRGDP

\begin{tabular}{|l|l|l|l|l|}
\hline Variable & Coefficient & Std.Error & t-Statistic & Prob. \\
\hline MCU(-1) & 1.256252 & 0.187804 & 6.689176 & 0.0000 \\
MCU(-2) & -0.411787 & 0.192849 & -2135280 & 0.0427 \\
NOEXP & $2.75 \mathrm{E} .06$ & $2.70 \mathrm{e}-06$ & 1.015690 & 0.3195 \\
C & 6.569069 & 3.885751 & 1.690553 & 0.1034 \\
R-Square & 0.903607 & Mean dependent var & & 46.44552 \\
Adjusted R-Square & 0.892040 & S.D. dependent var & & 10.43347 \\
S.E.of regression & 3.428153 & Akaike info criterion & & 5.429362 \\
Sum squared resid & 293.8058 & Schwarz criterion & & 5.617955 \\
Log likelihood & -74.72575 & Hannan-Quinn criter & & 5.488427 \\
F-statistic & 78.11841 & Durbin - Watson stat & & 2.142848 \\
Prob (F-statistic & 0.000000 & & & \\
\hline
\end{tabular}

Source: Computer analysis using E-views 9.0

\section{Granger Causality Analysis}

The effect of non-oil exports on economic growth in Nigeria was assessed using the granger causality between growth rate of real gross domestic product, manufacturing capacity utilization and non-oil exports in Nigeria as causality does not flow from either direction at 5\% significance level. This implies that non-oil exports have no significant effect on growth rate of real gross domestic product, agricultural contribution to real gross domestic product and manufacturing capacity utilization. However, there was evidence that agricultural contribution to real gross domestic product has significant effect on non-oil exports owing to the flow of causality from agricultural contribution to real gross domestic product to non-oil exports at $5 \%$ level of significance.

Table 15: granger Causality for Non-Oil exports and Economic Growth

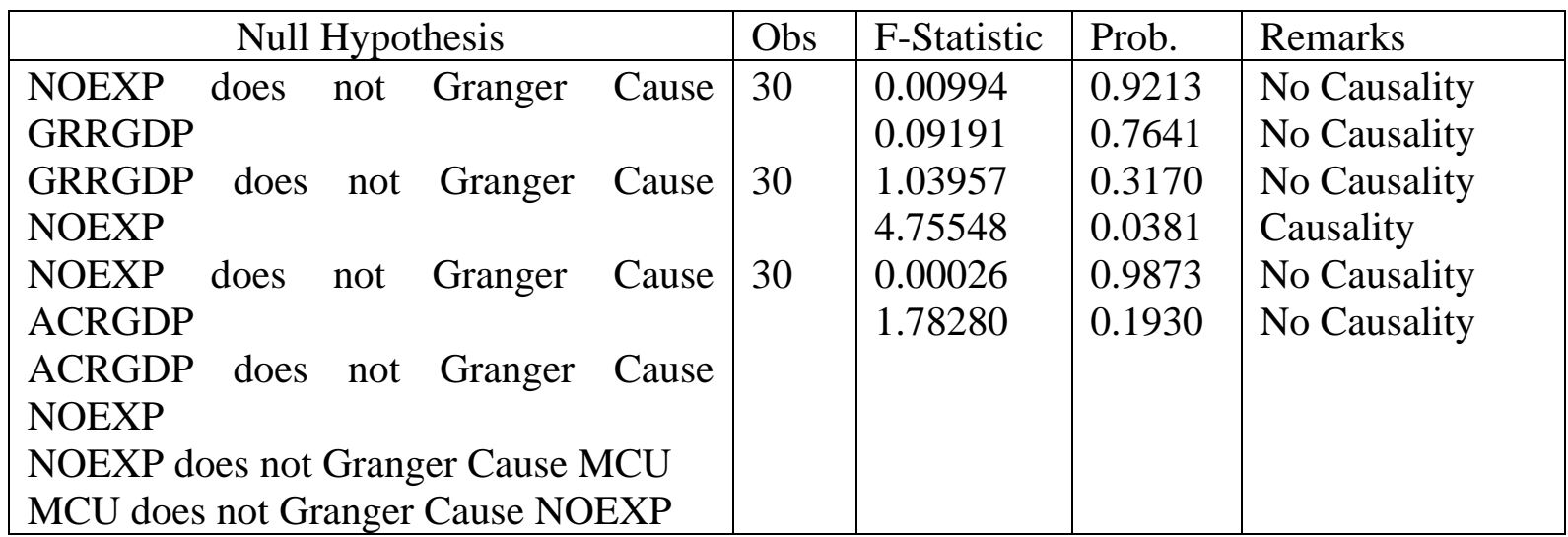

Source: Data output via E-views 9.0 


\section{Test of Hypotheses}

Decision Criteria: If the p-value of f-statistic in granger causality test is less than 0.05 , the null hypothesis is rejected. On the other hand, if the p-value of f-static granger causality test is greater than 0.05 , the null hypothesis is accepted.

Hypotheses One

H0: Non-oil exports have no significant effect on the growth rate of real gross domestic product.

\section{Table 16: Test of Hypothesis One}

\begin{tabular}{|l|l|l|l|}
\hline Estimated Model & F-statistic & P-value & Decision \\
\hline $\begin{array}{l}\text { GRRGDP } \rightarrow \text { NOEXP } \\
\text { NOEXP }\end{array}$ & $\mathbf{0 . 0 0 9 9 4}$ & $\mathbf{0 . 9 2 1 3}$ & Accept $\mathrm{H}_{0}$ and Reject $\mathrm{H}_{1}$ \\
\hline
\end{tabular}

Source: Granger Causality Output in Table 15

Table 16 shows that the p-value (0.9213) of the f-statistic (0.00994) is insignificant at 5\% significance level which is evidence that non-oil has no significant effect on growth rate of real gross domestic product. In this regard, the null hypothesis that non-oil has no significant effect on growth rate of real gross domestic product could not be rejected, while the alternate hypothesis could not be accepted.

Hypothesis Two

H0: Non-oil exports have no significant effect on agricultural contribution to real gross domestic product.

Table 17: Test of Hypothesis Two

\begin{tabular}{|l|l|l|l|}
\hline Estimated Model & F-statistic & P-value & Decision \\
\hline $\begin{array}{l}\text { ACRGDP } \rightarrow \text { NOEXP } \\
\text { NOEXP }\end{array}$ & $\mathbf{1 . 0 3 9 5 7}$ & $\mathbf{0 . 3 1 7 0}$ & Accept $\mathrm{H}_{0}$ and Reject $\mathrm{H}_{1}$ \\
\hline
\end{tabular}

Source: Granger causality Output in Table 15

As can be seen in table 17 , the p-value (0.3170) with f-statistic (1.03957) is greater than 0.05 , an indication that non-oil has no significant effect on agricultural contribution to real gross domestic product. Consequently, the null hypothesis that non-oil has no significant effect on agricultural contribution to real gross domestic product is accepted, whereas the alternate hypothesis is rejected.

Hypothesis Three

H0: Non-oil exports have no significant effect on manufacturing capacity utilization. 
Table 18: Test of Hypothesis Three

\begin{tabular}{|l|l|l|l|}
\hline Estimated Model & F-statistic & P-value & Decision \\
\hline $\begin{array}{l}\text { MCU NOEXP } \\
\text { NOEXP }\end{array}$ & 1.78280 & 0.1930 & Accept $\mathrm{H}_{0}$ and Reject $\mathrm{H}_{1}$ \\
\hline
\end{tabular}

Source: Granger causality Output in Table 15

By virtue of the p-value (0.1930) and f-statistic (1.78280) which is higher than 0.05 , non-oil exports have no significant effect on manufacturing capacity utilization. Therefore, the null hypothesis that non-oil exports have no significant effect on manufacturing capacity utilization is accepted, while the alternate hypothesis is rejected.

\section{DISCUSSION OF FINDINGS}

The Johansen co-integration result shows that there is a long run relationship only between non-oil exports and growth rate of real gross domestic product in Nigeria. This shows the role of non-oil exports in contributing to the growth of Nigerian economy which is largely dependent on oil revenue whose shock would have adverse effects on the economy. This assertion has been supported by the works of Gbaiye, Ogundipe, Osabuohien, Olugbire, Adeniran, Bolaji-Olutunji, Awodele and Aduradola (2013), Edeme, Ifelunini and Nkalu (2016) and Fiiwe and Turakpe (2017).

Evidence emanating from the ARDL regression result is that there is a positive but insignificant relationship between growth rate of real gross domestic product, agricultural contribution to real gross domestic product, manufacturing capacity utilization and non-oil exports. This proves that non-oil exports have the potential to improving economic growth in Nigeria and diversification from oil to non-oil exports would greatly reduce our over reliance on oil and increase our foreign exchange earnings. This result is in line with previous studies of Fiiwe and Turakpe (2017), Shah, Abrar-ulhag and Farooq (2015), Raj and Chand (2017), Nwodo and Asongwa (2017), Ugwuegbe and Uruakpa (2013). On the other hand, it would agree with the results of Ogunjimi, Aderinto and Ogunro (2015) and Faridi (2012) on the negative relationship between non-oil exports and economic growth.

The granger causality analysis discloses that non-oil export has no significant effect on economic growth of Nigeria. Put differently, non-oil exports have not contributed significantly to the economic growth of Nigeria within the period studied. This would be due to the lack of attention given to non-oil exports, especially agriculture following the discovery of oil in large quantities in the Niger Delta region. The insignificant effect of non-oil exports on economic growth validates the findings of Mustapha, Akinkuotu, Shiro and Yusuf (2013), and Forgha and Aquilas (2015). Nevertheless, the significant influence of non-oil exports on growth as found by Igwe (2015), Raheem (2016), Eze (2017), and Edeme, Ifelunini and Nkalu (2016) were not confirmed. 


\section{SUMMARY OF FINDINGS}

The effect of non-oil exports on Nigeria's economic growth was examined in this study. Specifically, the effect of non-oil exports on growth rate of real gross domestic product, agricultural contribution to real gross domestic product and manufacturing capacity utilization were examined and the result revealed the following:

Non-oil exports have no significant effect on the growth rate of real gross domestic product. There is an insignificant positive relationship between non-oil exports and the growth rate of real gross domestic product.

Agricultural contribution to real gross domestic product is not significantly affected by exports of non-oil products even though there is evidence of a positive but insignificant correlation between them

Manufacturing capacity utilization is not significantly influenced by variation in Nigeria's nonoil exports. Non-oil exports are positively associated with manufacturing capacity utilization.

\section{CONCLUSION}

The issue of accelerated economic growth is gaining much attention by many development economists. Trade theories have recognized the role of exports in stimulating the economy, especially in developing countries. Non-oil exports in Nigeria have not satisfactorily contributed to growth following the Structural Adjustment Programme (SAP problems and policies pursued by different administrations. With this scenario, this study concludes that economic growth in Nigeria has not been significantly affected by non-oil exports despite the various non-oil promotion strategies by the government.

\section{RECOMMENDATIONS}

Following the findings that emanated from this study, the following recommendations are made for consideration by decision makers.

Cost and access to financial services for non-oil exporters should be moderate or relaxed. High interest rates charged by commercial banks and little disbursement in terms of the volume of credit does not allow non-oil exporting industries to modernize outdated plants and machineries which result in poor quality of non-oil exports.

Domestic exporters should be given an equal status with their foreign competitors by enabling them to work in an undistorted market and policy environment. This can be achieved for instance by providing exporters an automatic access to foreign exchange for the purchase of their intermediate goods and also providing them a preferential interest rate on bank loans which is much lower from the interest rate paid on non-export loans.

The Central Bank of Nigeria should through the commercial banks, development banks (e.g NEXIM) should provide a hedging operation by taking a reverse position in the forward market or using options to provide exporters with foreign exchange at competitive rate. 


\section{Contribution to Knowledge}

The major contribution of this study to knowledge is in the use of growth rate of real gross domestic product instead of the actual real gross domestic product to measure economic growth which was lacking in previous studies in the subject area in the Nigerian environment.

\section{Suggestions for Further Studies}

This study empirical ascertains the effect of non-oil exports on economic growth of Nigeria. This study can be improved upon by applying disaggregated quarterly or monthly data to enhance the comparability of findings with the result of this present research work.

\section{REFERENCES}

Adeyemi, P. A., \& Olufemi, O.B. (2016). The determinants of capacity utilization in the Nigerian manufacturing sector. Journal of Economics and Sustainable Development. 7(5), 50-60.

Alam, F. \& Myovella, G. (2016). Causality between agricultural exports and GDP its implications for Tanzanian economy. Journal of Economics, Finance and Accounting. $3(1), 1-18$.

Amasike, U. J. (2017). Nigeria's non-oil exports and the quest for federalism. Retrieved on 25th February, 2018 from:

https://www.thisdaylive.com/index.php2017/07/31/nigerias-non-oil exports-and-thequest-for-federalism.

Anyanwu, F.A., Ananwude, A. C. \& Okoye, T. N. (2017). An empirical assessment of the impact of commercial banks' lending on the economic development of Nigeria. International Journal of Applied Economics, Finance and Accounting. 1(1), 14-29.

Central Bank of Nigeria (2016). Statistical bulletin. Retrieved from cbn.gov.ng.

Dunn, R. M., \& Mutti, J. H. (2004). Trade and growth. In International Economics, London: Routledge

Edeme, R. K., Ifelunini, I. A., \& Nkalu, N. C. (2016). A comparative analysis of the impact of agricultural exports on economic growth of ECOWAS countries. ACTA Oeconomica Pragensia, 24(5), 31-46.

Ekiran, J. O., Awe, I. T. \& Ogunjobi, J. O. (2014). Agricultural export and economic growth in Nigeria: a multivariate Johansen co-integration analysis. International Journal of Arts and Commerce, 3(3), 89-98.

Ewetan, O., facile, A., Urhie, E. \& Oduntan, E. (2017). Agricultural output and economic growth in Nigeria. Journal of African Research in Business \& Technology, DOI: $10.5171 / 2017.516093$.

Ewubare, D. D., Ajie, C. O. \& Ojiya, E. A. (2017). An examination of the impact of non-oil exports and economic growth in Nigeria: an ARDL approach. Centre for Promoting Education and Research, 3(5),25-43

Eze, O. M. (2017). Agricultural sector performance and Nigeria's economic growth. Asian Journal of Agricultural Extension, Economics \& Sociology, 15(1),1-13.

Faridi, M. Z. (2012). Contribution of agricultural exports to economic growth in Pakistan. Pakistan Journal of Commerce and Social Sciences, 6(1), 133-146. 
Fiiwe, J. L., \& Turakpe, M. (2017). A comparative analysis on the role of crude oil and nonoil exports on Nigerian economy. Equatorial Journal of Marketing and Insurance Policy. 2(2), 1-20.

Forgha, N. G. \& Aquilas, N. A. (2015). The impact of timber exports on economic growth in Cameroon: an econometric investigation. Asian Journal of Economic Modeling. 3(3),46- 60 .

Gbaiye, O. G., Ogundipe, A. Osabuohien, E. Olugbuire, O. O., Adeniran, O. A., BolajiOlutunji, K. A., Awodele, O. D. \& Aduradola, O. (2013). Agricultural exports and economic growth in Nigeria (1980-2010). Journal of Economics and Sustainable Development $=$, 4(16), 1-5.

Grossman, G.. \& Helpman, E. (1991). Innovation and growth in the global economy. MIT Press, Cambridge, MA.

Igwe, L.O. (2015). The impact of non-oil export on economic growth in Nigeria. International Journal of Social Sciences and Humanities Reviews, 5(2), 86-95.

Ijirshar, V. U. (2015). The empirical analysis of agricultural exports and economic growth in Nigeria. Journal of Development and Agricultural Economics, 7(3), 113-122.

Jeff- Anyene, S.E., Ezu, G. K. \& Ananwude, A. C. (2016). The contribution of the Nigerian banks to the promotion of non-oil exports (1990-2013).Asian Journal of Economics, Business and Accounting. 1(1), 1-3.

Kautoke-Holani, A. W. (2008). Agricultural export growth and economic development for Tonga: the quest for efficiency, (Doctoral Dissertation, Massey University, Albany, New Zealand).

Kromtit, J. M., Kanadi, C., Ndangra, D.P. \& Lado, S. (2017). Contribution of non oil exports to economic growth in Nigeria (1985-2015). International Journal of Economics and Finance, 9(4), 253-261.

Mohsen, A. S. (2015). Effects of oil and non-oil exports on the economic growth of Syria. Academic Journal of Economic Studies, 1(2), 69-78.

Mustapha, S. A., Akinkuotu, O., Shiro, A. A. \& Yusuf, I. A. (2013). Can non-oil exports boost agriculture sector performance in Nigeria? A tale for oil independence. Research Journal of Finance and Accounting. 4(19), 144-156.

Nwodo, O. S., \& Asogwa, F. O. (2017). Global integration, non-oil export and economic growth in Nigeria. Academic Journal of Economic Studies, 3(1), 59-67.

Ogunjimi, O., Aderinto, E. \& Ogunro, T. (2015). An empirical analysis on the relationship between non-oil exports and economic growth in Nigeria. International Journal of Academic Research in Business and Social Sciences, 5(12), 68-78.

Ohlan, R. (2016). Agricultural exports and the growth of agriculture in India. Agricultural Economics Czech, 59(5), 211-218.

Olajide, O. T., Akinlabi, B. H. \& Tijani, A. A. (2012). Agricultural resources and economic growth in Nigeria. European Scientific Journal, 8(22), 103-113.

Ouma, D., Kimani, T. \& Manyasa, E. (2016). Agricultural trade and economic growth in the East African community. African Journal of Economic Review, 4(2), 203-221.

Oyetade P. O., Shri, D. A. \& Nor, A. A. R. (2016). Agricultural export, oil export and economic growth in Nigeria: Multivariate co-integration approach. International Journal of Environmental \& Agriculture Research, 2(2), 64-72

Raheem, I. (2016). Analysis of the effects of oil and non-oil export on economic growth in Nigeria. Retrieved on 25th February. 2018 from https://hal.archieves-ouvertes.fr/hal$0401103 \mathrm{vs} 2$. 
Raj, S.K. \& Chand, P. P. (2007). Analysis of Fiji's export and its impact on economic growth. International Journal of Business and Social Research, 7(3), 1-14.

Robert, S. (2005). John Maynard Keynes: 1883-1946: Economist philosopher statesman, UK, Pan Macmillan Ltd.

Shah, S. W. A., Abrar ul haq, M. \& Farooq, R. M. A. (2015). Agricultural export and economic growth: a case study of Pakistan. Public Policy and Administration Research, 5(8), 88-96.

Shahbaz, M., Ahmad, K. \& Asad, M. I. (2010). Exports-led growth hypothesis in Pakistan: further evidence. Retrieved from ssm.com.

Simasiku, C. \& Sheefeni, J. P. S. (2016). Agricultural exports and economic growth in Namibia. European Journal of basic and Applied Sciences, 4(1),41-50.

Singh, T. (2010). Does international trade cause economic growth? A survey. The World Economy. 15(54), 12-43.

Todaro, M. P. \& Smith, S. C. (2011). Economic Development, USA: Addison Wesley. Ugwu, O. J. (2017). Implication of non-oil exports on Nigeria's economic growth. International Journal of Business and Management Invention, 6(9),97-103.

Ugwuegbe, S. U. \& Uruakpa, P. C. (2013). The impact of export trading on economic growth in Nigeria. International Journal of Economics, Business and Finance, 1(10), 327-341

World Bank (2007). Dealing with commodity price volatility in the developing countries: a proposal for a market-based approach. Discussion paper for the roundtable on commodity risk management in the developing countries 